Selcuk Journal of Agriculture and Food Sciences

http://sjafs.selcuk.edu.tr/sjafs/index

Research Article
SJAFS

(2021) 35 (1), 39-44

e-ISSN: 2458-8377

DOI: $10.15316 /$ SJAFS.2020.226

\title{
The Occurrence of Barley (Hordeum vulgare) and Wild Barley (H. spontaneum) Leaf Diseases in Batman Province and Surrounding Areas of Turkey
}

\author{
(D) Işıl SARAÇ SIVRIKKAYA ${ }^{1}$, (D) Aziz KARAKAYA2*, (D) Arzu ÇELİK OĞUZ \\ ${ }^{1}$ Bingöl University, Faculty of Agriculture, Department of Plant Protection, Bingöl, Turkey \\ ${ }^{2}$ Ankara University, Faculty of Agriculture, Department of Plant Protection, Ankara, Turkey
}

\begin{tabular}{|c|c|}
\hline ARTICLE INFO & ABSTRACT \\
\hline $\begin{array}{l}\text { Article history: } \\
\text { Received date: } 27.09 .2020 \\
\text { Accepted date: } 17.03 .2021\end{array}$ & $\begin{array}{l}\text { Barley (Hordeum vulgare) is an important crop in Turkey. In this study, } 37 \\
\text { barley fields in Batman central district and Beşiri (Batman), Gercüş (Batman), } \\
\text { Hasankeyf (Batman), Kozluk (Batman), Sason (Batman), Kocaköy (Diyarba- }\end{array}$ \\
\hline $\begin{array}{l}\text { Edited by: } \\
\text { Murat KARACA; Selcuk University, } \\
\text { Turkey }\end{array}$ & $\begin{array}{l}\text { presence of leaf diseases. In addition, } 24 \text { naturally grown wild barley ( } H \text {. } \\
\text { spontaneum) populations in Batman central district and Beşiri, Hasankeyf, } \\
\text { Kurtalan, and Midyat districts were inspected for the presence of leaf diseases. } \\
\text { In barley fields, scald caused by Rhynchosporium commune was the most }\end{array}$ \\
\hline $\begin{array}{l}\text { Keywords: } \\
\text { Barley } \\
\text { Barley diseases } \\
\text { Wild barley } \\
\text { Hordeum spontaneum } \\
\text { Batman } \\
\text { Turkey }\end{array}$ & $\begin{array}{l}\text { common disease, followed by the spot form of net blotch caused by Drechslera } \\
\text { teres f. maculata, barley stripe caused by Drechslera graminea, the net form of } \\
\text { net blotch caused by Drechslera teres f. teres, spot blotch caused by } \\
\text { Cochliobolus sativus, powdery mildew caused by Blumeria graminis f. sp. } \\
\text { hordei and brown rust caused by Puccinia hordei. Among the Hordeum } \\
\text { spontaneum populations the most common disease was scald, followed by the } \\
\text { spot form of net blotch, the net form of net blotch, powdery mildew, and brown } \\
\text { rust. }\end{array}$ \\
\hline
\end{tabular}

\section{Introduction}

Barley (Hordeum vulgare) is an important crop in Turkish agriculture. In 2019, barley was planted in 28690715 decares of the area in Turkey (TUIK 2020). Barley is used as feed, in malt production, and as green hay. Also, a limited amount of human food is produced (Geçit 2016). In this study, 37 barley fields in Batman central district and Beşiri (Batman), Gercüş (Batman), Hasankeyf (Batman), Kozluk (Batman), Sason (Batman), Kocaköy (Diyarbakır), Kurtalan (Siirt), and Midyat (Mardin) districts were examined for the presence of leaf diseases. In 2019, barley was planted in 15000, 20569,1650, 2733, 6800, 250, 3061, 14000 and 51978 decares of land in Beşiri, Gercüş, Hasankeyf, Batman central district, Sason, Kocaköy, Kurtalan and Midyat districts, respectively (TUIK 2020). Wild barley (Hordeum spontaneum), the progenitor of the modern-day barley cultivars, is common in the region. Hordeum spontaneum populations are important disease resistance sources (Çelik and Karakaya 2017).

\footnotetext{
* Corresponding author email: karakaya@agri.ankara.edu.tr
}

Additionally, 24 naturally grown wild barley ( $H$. spontaneum) populations in Batman central district and Beşiri, Hasankeyf, Kurtalan, and Midyat districts were inspected for the presence of leaf diseases in this study.

\section{Materials and Methods}

A survey was carried out in Batman province and surrounding areas of Turkey during April 2019. A total of 37 barley (Hordeum vulgare) fields and 24 naturally grown wild barley (Hordeum spontaneum) populations were examined. One, 1, 9, 6, 9, 6, 1, 1, and 3 barley fields in Sason, Kozluk, Beşiri, Batman central district, Hasankeyf, Gercüş, Kocaköy, Kurtalan, and Midyat districts respectively were examined for the presence of barley leaf diseases. Two, 8, 6, 2, 1, and 5 wild barley (H. spontaneum) field populations in Batman central district and Beşiri, Hasankeyf, Gercüş, Kurtalan, and Midyat districts respectively were examined for the presence of the leaf diseases. Barley fields and wild barley populations were examined every 2-30 kilometers (Aktaş 2001). At each barley field, at least 100 plants were examined. At least 50 wild barley $(H$. spontaneum) plants were inspected for the presence of the diseases at each location. The diseases were 
identified as described by Mathre (1997) and Zaffarano et al. (2011). When necessary, surface-sterilized leaf pieces were placed on blotter paper and conidia were examined under a stereomicroscope. A 1-9 scale developed by Saari and Prescott was used for the determination of the disease severity (Saari and Prescott, 1975).

\section{Results and Discussion}

Six, 1, 1, 9, 9, 6, 1, 1, and 3 barley fields in Batman central district and Sason, Kozluk, Beşiri, Hasankeyf and Gercüş districts and Kocaköy (Diyarbakır), Kurtalan (Siirt) and Midyat (Mardin) districts were examined for the presence of the barley leaf diseases. A total of 37 barley fields were inspected. Scald caused by the Rhynchosporium commune was the most common disease followed by the spot form of net blotch caused by Drechslera teres f. maculata, barley stripe caused by Drechslera graminea, the net form of net blotch caused by Drechslera teres f. teres, spot blotch caused by Cochliobolus sativus, powdery mildew caused by Blumeria graminis f. sp. hordei and brown rust caused by Puccinia hordei (Table 1). Scald was present in all districts with the exception of Kozluk and Kurtalan districts, however, only one field was examined in each of these districts. In 2 Beşiri fields and in one Hasankeyf field scald incidences were 100 percent with the severity values of 9 . In other fields, scald incidences were between 1-70 percent and severity values were between 5-7. Spot form of net blotch was present in 19 barley fields. In one Beşiri field spot form of net blotch incidence was 100 percent and in one Batman central district field spot form of net blotch incidence was 70 percent. In each of these fields, the disease severity value was 7 . In other fields, the spot form of net blotch incidence values were between 1-30 percent and the disease severity values were between 5-7, mostly an average of 5. Barley stripe caused by Drechslera graminea was present in 18 barley fields. In these fields, incidence values of barley stripe ranged from 1 to 30 percent. Barley stripe was present in all districts with the exception of Kozluk and Kocaköy districts, however, in each of these districts, only one barley field was inspected. Net form of net blotch was present in 6 barley fields. Net form of net blotch was observed in Beşiri, Hasankeyf, Gercüş and Midyat districts. The net form of net blotch incidence in these fields was between 1-10 percent and severity values were 5 in all fields. Powdery mildew was present in 2 Hasankeyf and Gercüss fields. In both fields, the incidence value of powdery mildew was 1 percent and severity values were 5 in both fields. Spot blotch was found in 2 Beşiri and Gercüş fields. The incidence values were 5 and 10 in Beşiri and Gercüş fields, respectively. The severity values in both fields were 5. Brownrust was detected only in Batman central district field. The incidence value of brown rust was 1 percent and the severity value was 5 in this district.
It appears that the main barley diseases in these areas are scald, net blotch, and barley stripe. Both forms of net blotch were observed, however, the spot form of net blotch was more prominent. Brown rust, powdery mildew, and spot blotch were observed in fewer fields. Scald, net blotch, and barley stripe were previously reported to be common in Turkey (Karakaya et al. 2014, Karakaya et al. 2016a). The other diseases reported in the current study were also detected in earlier studies in the barley fields of Turkey (Çelik and Karakaya 2015, Özdemir et al. 2017, İlgen et al. 2017, Ertürk et al. 2018). In Eskişehir province of Turkey, net blotch and scald were the predominant diseases followed by barley stripe, brown rust, powdery mildew, and Ustilago spp. (Çelik and Karakaya 2015). Both biotypes of net blotch were present in Eskişehir province. In the Kırıkkale province of Turkey, scald and net blotch were found to be the most common diseases (Özdemir et al. 2017). In the Kirıkkale province, spot form of net blotch was more common. In this province, powdery mildew and brown rust diseases followed this disease and in a few fields, yellow rust and stem rust also were observed. In another study conducted in the Çubuk district of Ankara province, scald caused by Rhynchosporium secalis was the most common barley disease followed by brown rust and net blotch. Both forms of net blotch were found in the Çubuk district. Barley stripe, yellow rust, stem rust, and powdery mildew were also found in Çubuk district fields (İlgen et al. 2017). In the Bala district of Ankara, the net form of net blotch was found as the most common disease followed by the spot form of net blotch and scald. Barley stripe and powdery mildew were also present in some fields in Bala district (Ertürk et al. 2018).

Two, 8, 6, 2, 1, and 5 wild barley (H. spontaneum) field populations in Batman central district and Beşiri, Hasankeyf, Gercüş, Kurtalan (Siirt), and Midyat (Mardin) districts were examined for the presence of diseases. No disease was observed at two $H$. spontaneum populations at Hasankeyf district (Table 2 ). Among the wild barley populations, the most common disease was scald, followed by the spot form of net blotch, the net form of net blotch, powdery mildew, and brown rust. Rhynchosporium commune was observed in 14 wild barley populations. The incidence values of $R$. commune in these populations ranged from 1 to 80 percent. Scald was present in 6 Beşiri populations with incidences in the range of 7-80 percent. In one Beşiri population disease incidence was 80 percent with a severity value of 9 . On the other hand, scald was found only in one Hasankeyf population with a disease incidence of 1 percent. Scald was detected in 2, 1 , and 3 populations from Gercüş, Kurtalan, and Midyat. The severity values of scald were most of the time 5. Spot form of net blotch was present in 1, 2, 2, 1, 1, and 1 wild barley populations in Batman central district and in Beşiri, Hasankeyf, Gercüş, Kurtalan, and Midyat districts, respectively. 
Disease incidence values in these populations were between 1-20 percent and disease severity values were between 5-9, mostly being 5 . Net form of net blotch was observed in 1, 1, and 2 wild barley populations from Beşiri, Hasankeyf, and Midyat districts, respectively. In these populations, disease incidence percentages ranged between 1-5 and disease severity value was 5 in all of these populations. Powdery mildew disease was detected in $1,1,1$, and 1 populations from Beşiri, Hasankeyf, Gercüş, and Kurtalan districts, respectively. In these populations, the disease incidence percentages ranged from 1 to 5 and the disease severity was 5 in all of these populations. Brown rust was detected only in one population from the Midyat district. In this population, the disease incidence was 10 percent and disease severity value was 5. Variation related to disease resistance was observed among the wild barley populations. Karakaya et al. (2016b) examined 40 naturally growing Hordeum spontaneum populations in Şanlıurfa, Gaziantep, Şırnak, Mardin, Diyarbakır, Siirt, Hatay and Kilis provinces of Turkey for the presence of the diseases. Scald caused by Rhynchosporium commune was the most commonly encountered disease. Powdery mildew and net blotch followed the scald disease. Both forms of the net blotch were found. In addition, semi-loose smut, loose smut, brown rust, and barley stripe were found in the $H$. spontaneum populations.

In the current study, scald and net blotch were common in the barley fields and wild barley populations examined. These two diseases appear to be the most common diseases in these areas. Barley stripe was also common in the barley fields investigated. Proper control methods should be implemented in regard to each of these diseases. Barley stripe disease can be controlled by using disease-free seed and/or treating the seed with fungicides. Also, cultural methods will help to reduce the disease. Resistant cultivars to barley stripe exist (Ulus and Karakaya 2007, Bayraktar and Akan 2012, Çelik et al. 2016).
Resistant cultivars to scald and net blotch are also present and can be employed (Mert and Karakaya 2004, Karakaya and Akyol 2006, Düşünceli et al. 2008, Taşkoparan and Karakaya 2009, Usta et al. 2014, Azamparsa et al. 2015, Yazic1 et al. 2015). Wild barley populations exhibiting no disease symptoms under natural conditions should be tested under controlled conditions against the major diseases of barley and may be used in disease resistance breeding studies.

\section{Conclusions}

In this study, 37 barley (Hordeum vulgare) fields and 24 naturally grown wild barley (Hordeum spontaneum) populations in Batman central district and surrounding areas were inspected for the presence of the leaf diseases. Among the barley fields, scald caused by the Rhynchosporium commune was the most common disease followed by the spot form of net blotch caused by Drechslera teres f. maculata, barley stripe caused by Drechslera graminea, the net form of net blotch caused by Drechslera teres f. teres, spot blotch caused by Cochliobolus sativus, powdery mildew caused by Blumeria graminis f. sp. hordei and brown rust caused by Puccinia hordei. Among the wild barley populations, the most common disease was scald, followed by the spot form of net blotch, the net form of net blotch, powdery mildew, and brown rust. Scald and net blotch were common among the barley fields and wild barley populations examined. These two diseases appear to be the most common diseases in these areas. Barley stripe was also common among the barley fields surveyed. Appropriate control methods should be implemented for these diseases. Wild barley populations that showed no disease under natural conditions should be tested under controlled conditions against the major barley diseases and could be used in breeding studies for disease resistance.

Table 1

Barley (Hordeum vulgare) leaf diseases observed at Batman province and surrounding areas of Turkey

\begin{tabular}{|c|c|c|c|c|c|c|c|c|c|c|c|c|c|c|c|c|}
\hline $\begin{array}{l}\mathrm{N} \\
\mathrm{O}\end{array}$ & $\begin{array}{l}\text { Provinc } \\
\mathrm{e}\end{array}$ & $\begin{array}{l}\text { Distric } \\
\mathrm{t}\end{array}$ & $\begin{array}{l}\text { Disease } \\
\text { situatio } \\
\mathrm{n}\end{array}$ & $\begin{array}{l}R . \\
\text { comm } \\
.\end{array}$ & $\begin{array}{l}R . \\
\text { comm } \\
.\end{array}$ & $\begin{array}{l}D t \\
m\end{array}$ & $\begin{array}{l}D t \\
m\end{array}$ & $D t t$ & $D t t$ & $\begin{array}{l}P . \\
\text { horde } \\
i\end{array}$ & $\begin{array}{l}P . \\
\text { horde } \\
i\end{array}$ & $\begin{array}{l}B g \\
h\end{array}$ & $B g h$ & $\begin{array}{l}\text { Coc } \\
h\end{array}$ & $\begin{array}{l}\text { Coc } \\
h\end{array}$ & $\begin{array}{l}D . \\
\text { gramine } \\
a\end{array}$ \\
\hline & & & & Inc. & Sev. & Inc. & $\begin{array}{l}\text { Sev } \\
.\end{array}$ & Inc & Sev & Inc. & Sev. & Inc & $\begin{array}{l}\mathrm{Sev} \\
.\end{array}$ & Inc. & Sev. & Inc. \\
\hline 1 & Batman & Sason & present & 3 & 5 & 3 & 5 & & & & & & & & & 1 \\
\hline 2 & Batman & $\begin{array}{l}\text { Koz- } \\
\text { luk }\end{array}$ & present & & & 3 & 5 & & & & & & & & & \\
\hline 3 & Batman & Beşiri & present & 70 & 7 & 30 & 7 & & & & & & & 5 & 5 & \\
\hline 4 & Batman & Beşiri & present & 30 & 5 & 20 & 5 & & & & & & & & & \\
\hline 5 & Batman & Beşiri & present & 25 & 5 & & & & & & & & & & & \\
\hline 6 & Batman & Beşiri & present & & & & & & & & & & & & & 2 \\
\hline 7 & Batman & Beşiri & present & & & & & & & & & & & & & 10 \\
\hline 8 & Batman & Beşiri & present & 2 & 5 & 10 & 7 & 2 & 5 & & & & & & & 1 \\
\hline 9 & Batman & Beşiri & present & 5 & 7 & 100 & 7 & & & & & & & & & 2 \\
\hline 10 & Batman & Beşiri & present & 100 & 9 & & & & & & & & & & & \\
\hline 11 & Batman & Beşiri & present & 100 & 9 & & & & & & & & & & & \\
\hline 12 & Batman & $\begin{array}{l}\text { Centra } \\
1\end{array}$ & present & 65 & 7 & & & & & 1 & 5 & & & & & 2 \\
\hline
\end{tabular}


Table 1

Barley (Hordeum vulgare) leaf diseases observed at Batman province and surrounding areas of Turkey

\begin{tabular}{|c|c|c|c|c|c|c|c|c|c|c|c|c|c|c|}
\hline 13 & Batman & Central & present & 15 & 5 & & & & & & & & & \\
\hline 14 & Batman & Central & present & 15 & 5 & & & & & & & & & \\
\hline 15 & Batman & Central & present & 5 & 5 & & & & & & & & & \\
\hline 16 & Batman & Central & present & 5 & 5 & & & & & & & & & \\
\hline 17 & Batman & Central & present & & & 70 & 7 & & & & & & & \\
\hline 18 & Batman & Hasankeyf & present & 60 & 7 & & & & & & & & & \\
\hline 19 & Batman & Hasankeyf & present & & & 10 & 5 & 1 & 5 & 1 & 5 & & & 3 \\
\hline 20 & Batman & Hasankeyf & present & 100 & 9 & & & & & & & & & \\
\hline 21 & Batman & Hasankeyf & present & 2 & 5 & 1 & 5 & & & & & & & \\
\hline 22 & Batman & Hasankeyf & present & 30 & 5 & & & & & & & & & 3 \\
\hline 23 & Batman & Hasankeyf & present & 3 & 5 & & & 10 & 5 & & & & & 13 \\
\hline 24 & Batman & Hasankeyf & present & & & 5 & 5 & 10 & 5 & & & & & \\
\hline 25 & Batman & Hasankeyf & present & 50 & 7 & & & & & & & & & \\
\hline 26 & Batman & Hasankeyf & present & 50 & 5 & & & & & & & & & \\
\hline 27 & Batman & Gercüş & present & 3 & 5 & & & & & & & 10 & 5 & 30 \\
\hline 28 & Batman & Gercüş & present & 5 & 5 & & & & & & & & & 3 \\
\hline 29 & Batman & Gercüș & present & 10 & 5 & 2 & 5 & 1 & 5 & & & & & \\
\hline 30 & Batman & Gercüş & present & 1 & 5 & 10 & 5 & & & & & & & 1 \\
\hline 31 & Batman & Gercüş & present & 5 & 5 & 3 & 5 & & & 1 & 5 & & & 1 \\
\hline 32 & Batman & Gercüş & present & 5 & 5 & 2 & 5 & & & & & & & 7 \\
\hline 33 & Diyarbakır & Kocaköy & present & 50 & 5 & 1 & 5 & & & & & & & \\
\hline 34 & Siirt & Kurtalan & present & & & 1 & 5 & & & & & & & 1 \\
\hline 35 & Mardin & Midyat & present & 5 & 5 & 5 & 5 & & & & & & & 2 \\
\hline 36 & Mardin & Midyat & present & 7 & 5 & 3 & 5 & 1 & 5 & & & & & 1 \\
\hline 37 & Mardin & Midyat & present & & & 20 & 5 & & & & & & & 1 \\
\hline
\end{tabular}

(R. comm: Rhynchosporium commune, Dtm: Drechslera teres f. maculata, Dtt: Drechslera teres f. teres, P. hordei: Puccinia hordei, Bgh: Blumeria graminis f. sp. hordei, Coch: Cochliobolus sativus, D. graminea: Drechslera graminea, Inc.: Incidence, Sev.: Severity)

Table 2

Wild barley (Hordeum spontaneum) leaf diseases observed at Batman province and surrounding areas of Turkey

\begin{tabular}{|c|c|c|c|c|c|c|c|c|c|c|c|c|c|}
\hline \multirow[t]{2}{*}{$\begin{array}{l}\mathrm{N} \\
\mathrm{o}\end{array}$} & \multirow[t]{2}{*}{$\begin{array}{l}\text { Provin } \\
\text { ce }\end{array}$} & \multirow[t]{2}{*}{ District } & \multirow{2}{*}{$\begin{array}{l}\text { Diseas } \\
\mathrm{e} \\
\text { situati } \\
\text { on }\end{array}$} & $\begin{array}{l}R . \\
\text { comm. }\end{array}$ & $\begin{array}{l}R . \\
\text { comm. }\end{array}$ & Dtm & Dtm & $\overline{D t t}$ & $\overline{D t t}$ & $\begin{array}{l}P . \\
\text { hordei }\end{array}$ & $\begin{array}{l}P . \\
\text { hordei }\end{array}$ & $B g h$ & $B g h$ \\
\hline & & & & $\begin{array}{l}\text { Inciden } \\
\text { ce }\end{array}$ & $\begin{array}{l}\text { Severit } \\
\mathrm{y}\end{array}$ & $\begin{array}{l}\text { Inciden } \\
\text { ce }\end{array}$ & $\begin{array}{l}\text { Severit } \\
\mathrm{y}\end{array}$ & $\begin{array}{l}\text { Inciden } \\
\text { ce }\end{array}$ & $\begin{array}{l}\text { Severit } \\
\mathrm{y}\end{array}$ & $\begin{array}{l}\text { Inciden } \\
\text { ce }\end{array}$ & $\begin{array}{l}\text { Severit } \\
\mathrm{y}\end{array}$ & $\begin{array}{l}\text { Inciden } \\
\text { ce }\end{array}$ & $\begin{array}{l}\text { Severit } \\
\mathrm{y}\end{array}$ \\
\hline 1 & $\begin{array}{l}\text { Bat- } \\
\text { man }\end{array}$ & Central & present & & & 1 & 3 & & & & & & \\
\hline 2 & $\begin{array}{l}\text { Bat- } \\
\text { man }\end{array}$ & Central & present & 50 & 5 & & & & & & & & \\
\hline 3 & $\begin{array}{l}\text { Bat- } \\
\text { man }\end{array}$ & Beşiri & present & & & 20 & 5 & & & & & & \\
\hline 4 & $\begin{array}{l}\text { Bat- } \\
\text { man }\end{array}$ & Beşiri & present & 7 & 5 & 1 & 5 & & & & & 1 & 5 \\
\hline 5 & $\begin{array}{l}\text { Bat- } \\
\text { man }\end{array}$ & Beşiri & present & 40 & 5 & & & & & & & & \\
\hline 6 & $\begin{array}{l}\text { Bat- } \\
\text { man }\end{array}$ & Beşiri & present & 80 & 9 & & & & & & & & \\
\hline 7 & $\begin{array}{l}\text { Bat- } \\
\text { man }\end{array}$ & Beşiri & present & 20 & 5 & & & & & & & & \\
\hline 8 & $\begin{array}{l}\text { Bat- } \\
\text { man }\end{array}$ & Beşiri & present & 20 & 5 & & & & & & & & \\
\hline 9 & $\begin{array}{l}\text { Bat- } \\
\text { man }\end{array}$ & Beşiri & present & 30 & 5 & & & & & & & & \\
\hline 10 & $\begin{array}{l}\text { Bat- } \\
\text { man }\end{array}$ & Beşiri & present & & & & & 5 & 5 & & & & \\
\hline 11 & $\begin{array}{l}\text { Bat- } \\
\text { man }\end{array}$ & $\begin{array}{l}\text { Hasan- } \\
\text { keyf }\end{array}$ & present & & & & & & & & & 2 & 5 \\
\hline 12 & $\begin{array}{l}\text { Bat- } \\
\text { man }\end{array}$ & $\begin{array}{l}\text { Hasan- } \\
\text { keyf }\end{array}$ & absent & & & & & & & & & & \\
\hline 13 & $\begin{array}{l}\text { Bat- } \\
\text { man }\end{array}$ & $\begin{array}{l}\text { Hasan- } \\
\text { keyf }\end{array}$ & present & 1 & 5 & & & & & & & & \\
\hline 14 & $\begin{array}{l}\text { Bat- } \\
\text { man }\end{array}$ & $\begin{array}{l}\text { Hasan- } \\
\text { keyf }\end{array}$ & absent & & & & & & & & & & \\
\hline 15 & $\begin{array}{l}\text { Bat- } \\
\text { man }\end{array}$ & $\begin{array}{l}\text { Hasan- } \\
\text { keyf }\end{array}$ & present & & & 20 & 7 & 1 & 5 & & & & \\
\hline 16 & $\begin{array}{l}\text { Bat- } \\
\text { man }\end{array}$ & $\begin{array}{l}\text { Hasan- } \\
\text { keyf }\end{array}$ & present & & & 7 & 7 & & & & & & \\
\hline 17 & $\begin{array}{l}\text { Bat- } \\
\text { man }\end{array}$ & Gercüş & present & 1 & 5 & & & & & & & 1 & 5 \\
\hline 18 & $\begin{array}{l}\text { Bat- } \\
\text { man }\end{array}$ & Gercüş & present & 5 & 5 & 5 & 5 & & & & & & \\
\hline
\end{tabular}


Table 2

Wild barley (Hordeum spontaneum) leaf diseases observed at Batman province and surrounding areas of Turkey

\begin{tabular}{|c|c|c|c|c|c|c|c|c|c|c|c|c|}
\hline 19 & Siirt & Kurtalan & present & 2 & 5 & 2 & 5 & & & & 5 & 5 \\
\hline 20 & Mardin & Midyat & present & & & 3 & 5 & 3 & 5 & & & \\
\hline 21 & Mardin & Midyat & present & 1 & 5 & & & & & & & \\
\hline 22 & Mardin & Midyat & present & 15 & 7 & & & & & & & \\
\hline 23 & Mardin & Midyat & present & & & & & & & 10 & 5 & \\
\hline 24 & Mardin & Midyat & present & 5 & 5 & & & 1 & 5 & & & \\
\hline
\end{tabular}

(R. comm: Rhynchosporium commune, Dtm: Drechslera teres f. maculata, Dtt: Drechslera teres f. teres, P. hordei: Puccinia hordei, Bgh: Blumeria graminis f. sp. hordei, Inc.: Incidence, Sev.: Severity

\section{References}

Aktaş H (2001). Önemli hububat hastalıkları ve sürvey yöntemleri. T.C. Tarım ve Köyişleri Bakanlığı. Tarımsal Araştırmalar Genel Müdürlüğü. Bitki Sağlığ1 Araştırmaları Daire Başkanlığı, Ankara, 74 s.

Azamparsa MR, Mert Z, Karakaya A, Sayim İ, Ergün N, Aydoğan S (2015). Determination of the seedling reactions of some barley cultivars and advanced barley lines to Rhynchosporium commune. Bitki Koruma Bülteni 55(3): 247-252.

Bayraktar H, Akan K (2012). Genetic characterization of Pyrenophora graminea isolates and the reactions of some barley cultivars to leaf stripe disease under greenhouse conditions. Turkish Journal Agriculture and Forestry 36: 329-339.

Çelik E, Karakaya A (2015). Eskişehir ili arpa ekim alanlarında görülen fungal yaprak ve başak hastalıklarının görülme sıklıklarının ve yoğunluklarının belirlenmesi. Bitki Koruma Bülteni 55(2): 157-170.

Çelik Y, Karakaya A, Çelik Oğuz A, Mert Z, Akan K, Ergün N, Sayim İ (2016). Determination of the reactions of some barley landraces and cultivars to Drechslera graminea. Akdeniz Üniversitesi Ziraat Fakültesi Dergisi 29(2): 43-47.

Çelik E, Karakaya A (2017). Yabani arpa (Hordeum spontaneum) ve hastalıklara dayanıkl1lık. Mustafa Kemal Üniversitesi Ziraat Fakültesi Dergisi 22(1): 65-86.

Düşünceli F, Çetin L, Albustan S, Mert Z, Akan K, Karakaya A (2008). Determination of the reactions of some barley cultivars and genotypes to scald under greenhouse and field conditions. Tarim Bilimleri Dergisi (Journal of Agricultural Sciences) 14(1): 46-50.

Ertürk H, Karakaya A, Çelik Oğuz A (2018). Leaf diseases occurring on barley plants in Bala district of Ankara province, Turkey. Ecological Life Sciences 13(4):204-207.

Geçit HH (2016). Serin İklim Tahılları (Buğday, Arpa, Yulaf, Triticale). Ankara Üniversitesi Ziraat Fakültesi Yayınları, Yayın No:1640. Ankara.

İlgen MZ, Karakaya A, Çelik Oğuz A (2017). Leaf diseases occurring on barley and wheat fields in
Çubuk district of Ankara, Turkey. Works of the Faculty of Agriculture and Food Sciences University of Sarajevo 67(2): 210-215.

Karakaya A, Mert Z, Çelik Oğuz A, Çetin L (2016a) Distribution of barley stripe disease in Central Anatolia, Turkey. Selcuk Journal of Agriculture and Food Sciences 30(2): 59-61.

Karakaya A, Mert Z, Çelik Oğuz A, Ertaş MN, Karagöz A (2016b). Determination of the diseases occurring on naturally growing wild barley (Hordeum spontaneum) field populations. Works of the Faculty of Agriculture and Food Sciences, University of Sarajevo 61(66/1), 291-295.

Karakaya A, Mert Z, Çelik Oğuz A, Azamparsa MR, Çelik E, Akan K, Çetin L (2014). Current status of scald and net blotch diseases of barley in Turkey. In: IWBLD - 1st International Workshop on Barley Leaf Diseases, June 3-6, 2014; Salsomaggiore Terme, Italy.

Karakaya A, Akyol A (2006). Determination of the seedling reactions of some Turkish barley cultivars to net blotch. Plant Pathology Journal 5(1):113114.

Mathre DE (ed.) (1997). Compendium of barley diseases (2nd ed.). APS Press, Minnesota, 120 pp.

Mert Z, Karakaya A (2004). Assessment of the seedling reactions of Turkish barley cultivars to scald. Journal of Phytopathology 152(3): 190-192.

Özdemir HY, Karakaya A, Çelik Oğuz A (2017). Kırıkkale ilinde buğday ve arpa ekim alanlarında görülen fungal yaprak hastalıklarının belirlenmesi. Bitki Koruma Bülteni 57(2): 89-112.

Saari EE, Prescott JM (1975). A scale for appraising the foliar intensity of wheat diseases. Plant Disease Reporter 59: 377-380

Taşkoparan H, Karakaya A (2009). Assessment of the seedling reactions of some barley cultivars to Drechslera teres f. maculata. Selçuk Tarım ve Gıda Bilimleri Dergisi 23(50):60-62.

TUIK (2020). Production statistics. https://biruni.tuik.gov.tr/medas/?kn=92\&locale $=$ tr , (access date:13.03.2021). 
Ulus C, Karakaya A (2007). Assessment of the seedling reactions of some Turkish barley cultivars to barley stripe. Tartm Bilimleri Dergisi (Journal of Agricultural Sciences) 13(4): 409-412.

Usta P, Karakaya A, Çelik Oğuz A, Mert Z, Akan K, Çetin L (2014). Determination of the seedling reactions of twenty barley cultivars to six isolates of Drechslera teres f. maculata. Anadolu Tarım Bilim- leri Dergisi (Anadolu Journal of Agricultural Sciences) 29(1): 20-25.

Yazıcı B, Karakaya A, Oğuz AÇ, Mert $\mathrm{Z}$ (2015). Determination of the seedling reactions of some barley cultivars to Drechslera teres f.teres. Bitki Koruma Bülteni 55(3): 239-245.

Zaffarano PL, McDonald BA, Linde CC (2011). Two new species of Rhynchosporium. Mycologia 103: 195-202. 